\title{
Learning Development and Education for Sustainability: what are the links?
}

\section{Jennie Winter}

Plymouth University, UK

\section{Graham Barton, FHEA}

University of the Arts London, UK

\section{Joseph Allison}

Plymouth University, UK

\section{Debby Cotton}

Plymouth University, UK

\section{Abstract}

Learning Development (LD) is an emerging discipline developing a unique disciplinary identity. In common with many other new fields, it considers its position and relevance to other disciplines and bodies of thought, and in particular, educational development, applied linguistics and the sociology and philosophy of education. This paper considers one such area of debate: the link between Learning Development and Education for Sustainability (EfS). EfS is an area of pedagogic practice and a field of enquiry of considerable and growing importance in Higher Education (HE) and universities. Its underpinning systemic and epistemic philosophies suggest the need for integration across all facets of university activity, including LD. In this paper, we argue that there are identifiable links between LD and EfS that extend these philosophies, practices and fields of enquiry, characterised by the following: 1) commonalities surrounding the foci of their pedagogic practices, 2) shared methodologies for undertaking their practices, and 3) ways in which these methodologies are helping to situate both professions and disciplines within organisational contexts. The commonalities and possible distinctions between LD and EfS form a starting point for discussion, and raise the possibility that explicit identification of the links may encourage increased collaboration between the respective communities of practice, and the development of new ideas and innovative practices. 
Keywords: sustainability literacy; academic fluency; systemic thinking; transformation; application to practice.

\section{Introduction}

\section{Overview - Learning Development}

The emergence of Learning Development (LD) has come about as a result of competing agendas and turbulent times. The considerable expansion of the Higher Education (HE) sector in the early 1990s, a corresponding increase in participation rates, and a relative decline in public funding resulted in students being drawn from an increasingly diverse 'range of educational, cultural and linguistic backgrounds' (Lea and Stierer, 2000, p. 2), with seemingly less time afforded to tutor contact. It was in response to this, recognising the need to support these students in their academic studies, that LD was first conceptualised (Hilsdon, 2011). As it has developed its range of pedagogic practices, philosophies and fields of enquiry, LD is notable in its student-facing work practices that perhaps distinguish it from other educational development practices: while educational developers work predominantly with academic staff and departments (for example through validation, teacher development and curriculum enhancement), LD is concerned with bringing these developmental perspectives to the student experience directly, not only for the benefit of student learning but also as feedback loops into institutional processes and contexts such as assessment design. LD is therefore focused on exploring with students how they learn, how they make sense of academic conventions, and how they can increase levels of enquiry into, and critical participation in, such conventions and practices. Further, it supports students in holistic development and in acquiring the generic underpinning skills appropriate to the environment in which they are working (ALDinHE, 2013). LD promotes the development of students' academic 'voice' through enhancing their understanding of academic conventions, developing critical thinking and reflection strategies, written and verbal communication skills, writing and creativity. It is oriented towards creating conditions for learners to increase awareness of learning processes, purposes and conditions, in turn giving them the ability to accomplish various academic practices, and to extend possibilities for situating themselves meaningfully, personally and professionally. Whilst this is, of course, also the domain of formal curricula, LD emphasises the value for learners of viewing disciplinary contexts from a different, reflective perspective in order for an individual to become more aware of the development 
of his or her capacities, capabilities and competences. LD is as much about developing awareness and criticality as it is about developing a pre-determined set of skills, literacies or capabilities.

\section{Overview - Education for Sustainability}

The world is facing many issues including economic austerity, social and economic inequality, threats to food security, increased health risks, climate change, shrinking biodiversity, and declining water and fossil fuel resources. This has led to increasing support for 'sustainable development'; development that recognises the interlinked nature of society, economy and environment and that can 'meet the needs of the present without compromising the ability of future generations to meet their own needs' (WCED, 1987, p.16). This involves changes in the way we think to develop more sustainable ways of living and working and Education for Sustainability (EfS) has been developed to help facilitate this. Sterling (2012, p. 9) defines EfS as 'about the kinds of education, teaching and learning that appear to be required if we are concerned about ensuring social, economic and ecological wellbeing, now and into the future. It helps people to cope with, manage and shape social and ecological conditions characterised by change, uncertainty, risk and complexity.

Within the education sector, HE has been identified through a series of United Nations and International University agreements as uniquely placed to take a leading role in implementing EfS - Talloires Declaration, 1990 (UNESCO, 1990); Halifax Declaration, 1991 (Lester Pearson Institute for International Development, 1992); Copernicus Charter, 1993 (CRE-Copernicus, 1994); Bonn Declaration (UNESCO, 2009). In reality, however, progress has been variable because of the conceptual and logistical challenges EfS poses. EfS has developed from philosophical underpinnings in technorationalism; the belief that technology is the rational and scientific means to solve sustainability issues and has typically focused on information provision and technological developments as ways to foster pro-environmental and pro-sustainable behaviour change. However, regardless of growing scientific consensus around the impeding impacts of climate change, peak oil and associated sustainability issues, individuals, organisations and industry have resisted changes which impact on their lifestyles, culture and prosperity (Harich, 2010). Greater understanding of the cultural implications of sustainability change has led educators to explore and foster interpretivist and socially critical approaches (Robottom and Hart, 1993) 
which emphasise metacognitive competency, self-reflection and awareness of the interconnectedness of human and natural systems (Sterling, 2004). In an HE context, this involves the development of systemic and epistemic thinking skills within individual learners, within and beyond curricula; responses that transcend discipline and other models of institutional organisation and call for institutional and organisational transformation.

EfS is challenging for an HE sector which is rooted in disciplinary traditions (Becher and Trowler, 2001) and has traditionally objectified learning (Bekir and Wiley, 2007), through prioritising the transmissive delivery of content-based curricula rather than focusing on developing student understanding and practices However, and conversely, 'enormous potential exists for universities to be leaders in challenging the status quo, challenging paradigms and openly practising new ways of living, teaching and learning' (Moore, 2005 p.78). Universities are ideal sites in which to present and debate the ideological struggles of society (Castells, 2001) and there is increasing political, scholarly and student support for this agenda (Bone and Agombar, 2011; Drayson et al., 2012).

\section{Discussion}

Already, in the brief descriptions of EfS and LD above, some common themes emerge which indicate the existence of commonalities between these two fields of work. In the context of $\mathrm{HE}$, the focus of work has tended to rest on the development of relevant literacies and cognition, with both areas moving in recent years towards support for metacognition and, particularly in the case of sustainability, to developing systemic understanding alongside sustainability literacies such as self-reflection and resilience (Sterling, 2010-11). Similarly, the pedagogic practices used to develop such literacies share similarities, as well as many of the constraints (discussed further below). Both LD and EfS pedagogies are underpinned by a philosophical stance that encourages a focus on interpreting and influencing the conditions of learning and the learning ecology or eco-system under which understandings are developed and emerge. This systemic viewpoint leads us to propose that within the context of $\mathrm{HE}$, both fields have emerged as organisational responses to a changing environment, associated with increasing levels of complexity in learning contexts, and are continuing to evolve within this system. In recognition of these similarities, this paper sets out suggestions for building a symbiotic relationship between LD and EfS in terms of: 
1) Commonalities surrounding the foci of their pedagogic practices.

2) Shared methodologies for undertaking practices.

3) Ways in which these methodologies are helping to situate both professions and disciplines within organisational contexts.

These are now considered in turn.

\section{1) Commonalities surrounding the foci of pedagogic practices}

Commonalities exist between some aspects of sustainability literacy and literacies associated with academic study practices, not least in shared approaches and understandings of the underpinning conditions required for individual development. The focus of work in LD has evolved via models of information deficit to current conceptions around developing appropriate literacies and discourses, as well as learner meta-cognition (Burgess et al., 1998; Skillen et al., 1998). EfS is similarly concerned with the emergence of different discourses and systemic ways of thinking (Sterling, 2003). Key to this process is the development of holistic understanding which underpins capacity to learn, to influence, to inspire, to communicate, to assimilate, to evaluate; to innovate, to implement and to organise within a whole systems-based world view. This whole-systems view, as conceived by Sterling (2003), is, we argue, central to the links between EfS and LD practice. However, the vocationalisation and rationalisation of HE has popularised discourses around generic skills, competencies and literacies, perhaps limiting wider recognition of the potential of whole-systems-based views for deep learning; these patterns are echoed within both LD and EfS.

As in LD, there has been much debate about content versus competencies in EfS (Forum for the Future, 2008; Hesselbarth and Schaltegger, 2014), particularly in HE where knowledge is often atomised within disciplines. Sterling (2012) argues that sustainabilityrelated content in the curriculum should be seen as a contributory part of broader pedagogical processes that encourage the sustainability-literate and competent graduate to develop. The sustainability-literate graduate may have declarative specialist knowledge, but in order to contribute to more sustainable ways of working and living they must be competent change agents to put to good use the knowledge they have. Research 
demonstrates exactly this; for example, Terenzini et al. (1995) highlighted the way in which factual knowledge obtained at university becomes outdated or forgotten, thus making critical thinking an essential and longer-lasting outcome of HE. Hesselbath and Schaltegger (2014) report that out of the top 15 competencies as perceived by MBAqualified sustainability practitioners, only two are subject specific. The others included selfinitiative, analytical skills, communication skills, self-management, presentation techniques, 'self-learning skills' (meta-cognitive skills), the ability to handle criticism, and project management. Tapper (2004) and the Scottish Executive (2003) report that students' capacity to engage in reflexive lifelong learning and adopt a sustainable approach is fundamental for graduates' personal and professional futures, and Ryan and Cotton (2013) and Sterling (2001) emphasise the integral role of critical thinking in facilitating this.

Through developing skills such as critical thinking, there is the potential to strengthen student engagement in aspects of sustainability literacy and broader understanding of LD. This moves us to broader conceptions of learning and development towards the work of Villiers-Stuart and Stibbe (2009), who identify a range of sustainability literacies. Of note in these literacies, and echoing Sterling's (2003) perspectives, is the emphasis on the need to encourage learners to deepen awareness of values, systems thinking and complexity. Although LD is beginning to extend its attention to these literacies alongside its focus on skills for learning, we suggest that these are not foregrounded in the LD literature. However, increased focus on these literacies could have significant impact on the ability of a student to perceive the underlying structures and nature of their discipline, and in turn, such awareness can help students perceive the forms and structures underlying disciplinary ways of thinking and practising. Therefore, as noted by Perkins $(2006$, p.43) in relation to student epistemic development: '...many students never get the hang of it, or only slowly, because the epistemes receive little attention. Surfacing the game through analytic discussion and deliberative practice could make a big difference'. We argue that this orientation to surfacing 'the game' (of HE practice) aligns with the current ethos and approaches of LD work.

There appears to be broad agreement that the primary focus of LD in HE is student learning, not through a technical-instrumentalist curriculum of 'skills' but by taking into account the social and experiential factors involved in learning, and thus empowering students in interpreting and making sense of HE practices (Hilsdon, 2011). In doing so, 
this approach is intended to not view students from a deficit perspective, where the focus is remedial and defined by their needs, but as 'transformative' with students actively analysing and assessing their own development (Hilsdon, 2011). Underpinning these transformational aspects lie theoretical and philosophical positions found in both LDrelated literature and in the sustainability literature. In LD, pedagogic approaches are informed by ethnographic, linguistic and socio-cultural fields of enquiry, and associated analytical approaches (Lea and Street, 1998; 2006; Lillis and Scott, 2007; Coffin and Donahue, 2012). In sustainability, such underpinnings are explored by Sterling (2010-11) and Bawden (2005), via Gregory Bateson's (1972) learning levels and Sterling's (2010) notion of learning as sustainability. Transformational learning requires not only learning to learn and learning about learning, but ultimately, learning how to learn about learning (Bawden, 2005; Sterling, 2010-11), a far deeper level of self-awareness and resilience that emerges from systemic perspectives; indeed, systems views have been identified by Sandri (2013) as threshold in nature (Meyer and Land, 2003). The associated transformational perspective could provide a mutually reinforcing point of commonality for the respective practices of LD and EfS. The consideration of this transformational or transforming, systemic, perspective moves us beyond a discussion of skills development to examine other links between these disciplines.

\section{2) Shared methodologies for undertaking practice}

Having sketched out similarities in pedagogic foci in the context of literacies, there is further congruence in the methodologies behind the work carried out by LD and sustainability practitioners. Continuing with a whole-systems perspective, both disciplines are engaged within organisational contexts in systemic ways, as a complement to the shared foci on inter- and trans-disciplinary contexts and deep learning. At a theoretical level, both EfS and LD are guided by and promote similar approaches to, and virtues of, learning, such as interactive, experiential, active, critical, interpretive and uncertain (Cotton and Winter, 2010; Foster, 2011). Indeed, numerous models and theories that underpin both fields share many similar qualities, for example: academic literacies; taking account of the social and experiential elements of learning (Lea and Street, 1998; 2006), systems thinking (Sterling, 2012); holistic/cross-disciplinary approaches and the inter-connected nature of thinking (WWF, 2005), reading, writing, studying, critical thinking or critical beings; communities of practice (Lave and Wenger, 1991); becoming legitimate 
participants in HE; and social and collaborative approaches to learning, all of which indicate less atomised skills development and a much more deeper connection. However, as this field of practice has grown over the past decades, so too has the dependency of academic tutors on its role in addressing key academic tasks, such as writing and critical analysis. In reality this relationship is often exercised through additional lectures aimed at addressing specific areas or 'skills' with little context, or through direct referral of 'struggling' students to gain additional support, again without reference to the academic context. In response, learning developers are continually improving ways in which to situate LD work within curricula, for example, through building on writing in the disciplines approaches (Deane and O'Neill, 2011) in order to offer assistance at the time of greatest motivation to engage with disciplinary discourses. However, without emphasising the systemic influence of LD work on institutional (primarily educational) practices, processes and operations, this evolving practice of LD could slip away from its underpinning philosophy that seeks to enhance generative conditions for learning.

Seeing both fields as trans-disciplinary and 'additional' to existing ('core') curricula denies the potential for increasing the range of investigative approaches to which a student has access in order to engage with academic study practices. As a result, LD work is becoming increasingly embedded within the disciplines, both within and alongside the curriculum. This embedded approach offers opportunities for the development of methodologies that incorporate ways to develop students' relational analytical skills and systemic thinking, required for epistemic cognition and orientations towards sustainability. To encourage greater emphasis on epistemic investigation, we propose that the focus of EfS and LD therefore extends towards the 'processes that help learners engage with and internalise a systems view of the world' (Sandri, 2013, p.820), or rather to a systems view of their discipline. This shift echoes the views of Perkins noted above, and by Sandri, that 'deep learning is particularly crucial in the case of sustainability education, where holistic insight and an ability to organise and structure disparate types of information into a coherent whole is central to the whole exercise' (Warburton, 2003, p.45). We argue that this holistic insight is also central to the whole exercise of LD.

The convergence of EfS and LD lenses towards exploring the holistic nature of disciplines with, for and by learners is echoed in fields similar to LD; there are parallels with other fields of study into academic study practice, language and disciplinarity, such as academic literacies, English for Academic Purposes (EAP) and increasing the focus of applied 
linguistics on disciplinarity and learning (Christie and Maton, 2011). This is arguably a natural outcome of orientations towards the holistic: both LD and sustainability disciplines operate within a complex social eco-system or learning ecology, and while acknowledging the fluidity of social systems, it seems that LD and EfS have become stable forms within HE institutions. This institutional context is now explored below.

\section{3) Ways in which these methodologies are helping to situate both professions and disciplines within organisational contexts}

Pedagogic practices in LD and EfS are both underpinned by a philosophical stance that encourages a focus on influencing the conditions under which learning and sustainability are developed and/or emerge. LD continues to operate within a supporting and developmental role, thereby contributing to sustainability education through developing similar literacies and abilities. Alongside this philosophical stance, there is a strong connection in the ways that both LD and EfS are often perceived in the wider sector. Through helping develop skills for learning in particular contexts, LD and sustainability are vying for space in curricula that are already thought of as over-crowded (Sterling, 2004), and when looked at in this way they have in the past been perceived as nothing more than simple add-, or bolt-ons (Wingate, 2006). Ironically, to view such activities as bolt-on might indicate a mechanistic, instrumentalist perspective borne out of the market-oriented social paradigm; in whole systems thinking terms, there would perhaps be no such thing as bolt-on. Accordingly, despite greater recognition of the role and influence of LD and EfS on students' learning, recognising and supporting links between these two fields may help to strengthen their place in universities, particularly given their potential for contributing to a generative learning ecology that encourages deep learning approaches outlined in this paper.

Going further, though, we argue that LD could be positioned to co-develop as a discipline and practice within inter- and trans-disciplinary contexts informed by sustainability. LD departments can help further develop the mechanisms and processes designed to support sustainability agendas at an institutional level, particularly through encouraging so-called 'sustainability pedagogies' such as problem- and scenario-based learning, contextual studies workshops, workshops for deepening reflective practice, and cross-disciplinary, collaborative, courses and projects. Such positioning could reinforce both LD research and 
practice, as LD's multi-, cross- and trans-disciplinary roles result in LD both working with students and as an institutional enabler for sustainability, alongside its support for curricula aims. As a point of focus for analysis, identification and criticality, this extra-curricular space offers meaningful material to engage students with LD and EfS methodologies. The position adopted in this paper points to the potential for LD and EfS to undertake collaborative educational research to enhance the methodologies and practices adopted within this shared extra-curricula space.

In parallel, both LD and EfS promote the inclusion of the student voice and the democratisation of learning in $\mathrm{HE}$; as such their perspective is of primary importance as a feedback loop into the curriculum, its content and delivery. In this article, we propose that LD itself is exhibiting pedagogic practice and themes characteristic of whole systems thinking, such as a focus on conditions, increasing clarity of purpose and the recognition of the role of emergence in learning. Through working with learners directly, LD practitioners recognise the influence of systemic conditions, moving their work beyond a deficit approach towards helping students understand learning. As a result, there is a sense that although LD has been operating within the constraints of the pervading paradigm, it also offers a challenge to the status quo and provides momentum towards an emergent systems view. Learning developers create feedback loops into organisational understanding and processes through engagement in co-teaching and co-delivery to embed support and a quasi-educational development role. In so doing, learning developers recognise that many of the issues and challenges for students are a result of conditions that are not solely in the domain or control of such learners. This awareness of complexity and associated systemic awareness appears to be emerging in the LD community and could be developed further in its practice.

Notwithstanding the tensions between transformative learning approaches and instrumentalism noted earlier, there might be potential in acknowledging the 'triumvirate' of EfS, LD and employability agendas in HE. EfS and LD contribute to fostering 'twenty-first century graduate attributes' which are responsive to the requirements of a knowledge economy and super-complexity. In this scenario the emphasis is on what students can do rather than what students know, highlighting metacognition as a priority (Barnett, 2000). Employers have long been interested in recruiting students with good academic literacy and there is emerging evidence that employers are also seeking sustainability and 'green economy' skills (BIS, 2008-9; 2010; HMGov, 2011). This is echoed by the student body: Bone and Agombar (2011) and Drayson et al. (2012) found that HE students believed that 
possession of sustainable development skills was significant for their degree course and for future employment. Arguably employability and enterprise cultures dominate contemporary HE (Robertson, 2000), therefore developing mutual links between these and other agendas can help to foster and consolidate institutional and academic support for students. However, there are issues with portraying either EfS or LD as reducible to a list or skill-set only which we must acknowledge. EfS requires that skills are embedded within assumptions and values that cultivate dispositions to challenge the political-economic status quo and that support change for sustainability: knowing 'how to' is not enough, as there has to be autonomous motivation to engage with change processes, critically or otherwise. Although these debates are not the main focus of this paper, they are noted here for their influence on both EfS and LD communities of practice.

\section{Recommendations for practice}

Making actual and potential links between EfS and LD explicit is one of the purposes of this paper, but what is perhaps more challenging is thinking about how these links are communicated; both between ourselves as practitioners and to the student population. It is likely that when considering how EfS sits within practice, learning developers experience similar barriers to embedding sustainability as do other HE professionals. These include the lack of shared understanding and language; 'definition dementia' (Reid and Petocz, 2006), the discipline focused nature of academic work (Wals and Jickling, 2002), the perceived irrelevance of ESD and lack of time and space in the curriculum (Dawe et al., 2005; Velazquez et al., 2005) and the impact of lecturers' attitudes towards sustainable development (Cotton et al., 2009, p.730). Seeking out those who are involved with delivering EfS can help to mitigate these issues and there are numerous toolkit resources available online (Stibbe, 2009; Cotton et al., 2012; Sterling, 2012; PU, 2014). Similarly, those tasked with delivering EfS can struggle with its complexity and may welcome sharing ideas and support from learning developers about how to embed the meta-cognitive and academic literacy component into their work.

Being aware of the basic principles and practices of EfS opens up opportunities for learning developers to use sustainability-related examples in practice, for example, critical thinking and communication as a shared core competency. Similarly, methodologies to develop relational, lateral, and systemic cognition run through creative arts, media, and 
performance education, and can be drawn upon by both LD and EfS pedagogic communities: contextual studies and collaborative units are common, and the use of object-based learning (Paris, 2002) is notable for the development of lateral and holistic awareness in learners through its focus on encouraging learners to 'read' material culture (Prown, 1982) and to engage with the learning potential of haptics (Willcocks, 2015). In terms of selecting texts for writing and LD work, sustainability-themed material could be used, in the first instance, to introduce and debate controversial issues (Cotton and Winter 2010; Oulton et al., 2004) to help students distinguish between forms of reasoning (sound and unsound), to develop a respect for evidence and open-mindedness, to develop understanding that true balance is incommensurable, and to help students develop a critical awareness of bias. Indeed, the growing literature on sustainability in multiple and diverse disciplines provides the very thread of continuity and fruitful sources of written text needed by learning developers working with any group of learners from multiple disciplines. Many learning developers and linguists/EAP practitioners invest much energy selecting inclusive texts intended to be meaningful to all students within a multi-disciplinary session, a widespread dilemma in such pedagogic settings where student writing is developed in multi-disciplinary classes, for example (Swales, 2009). In these contexts, the common thread of sustainability might provide a first port of call to help learning developers select meaningful texts, as well as to surface any potential commonalities between disciplines. This draws attention to a distinction as to how the budgets of EfS and LD departments tend to be allocated: a significant proportion of LD budget is often spent offering direct support to students on particular discipline-specific assignments through one-to-one tutorials and embedded sessions. Alongside this, LD teams offer open workshops on academic study topics that are relevant to multi-disciplinary groups. These latter settings are where the convergence of topics could be generative, such as the focus on sustainability discourses of particular disciplines, and in bringing LD lenses to the problem-based and scenario-based learning approaches in use by EfS practitioners.

Linking EfS with LD also offers LD practitioners an excellent position from which to collaborate with academic partners, an area where tensions can exist. Despite the principles described above, in practice, academic support is often requested as a 'bolt-on', to address an apparent student deficit, with repeat requests coming year after year. Reframing LD work through directing attention to epistemic cognition, through engagement with sustainability issues and associated cognition or knowledge practices of a given discipline, may ensure a resilient response to critiques of LD as 'bolt-on' work, and 
encourage co-teaching with discipline-based academics. As noted above, embedded approaches have evolved as a reaction to previously instrumental approaches to writing development and study skills and through a desire to respond to student experiences in anticipatory ways. Embedding LD into curricula and focusing work on particular troublesome knowledge has itself emerged from learning developers' recognition of the intrinsic inter-connectedness of language and thought, context and purpose, process and production; sustainability is a mindset that has arguably arisen from a similar awareness of interconnectedness. By foregrounding epistemes with students, learning developers are not only helping to 'surface the game' (Perkins, 2006), but arguably helping to develop the transdisciplinary, interconnected awareness necessary for sustainable futures.

\section{Conclusions}

The argument put forward here is that both EfS and LD share an emphasis on critical thinking and development of student skills, a focus on understanding individual values, beliefs and disciplinary ways of thinking and knowing, and a belief that holistic and embedded approaches have greater effect on student and staff development. Helping learners become aware of the purposes and processes of learning in varied ways is essential for sustaining through-life learning and thus engaging in appropriate responses to unpredictable future sustainability issues. The shared purposes of LD and EfS - on both staff and student development - provide a natural context for symbiotic relationships to emerge. Through developing shared understanding between the two areas, students may become more effective learners and be encouraged to navigate complexity, including that inherent within disciplinary knowledge. Focusing on the bounded social contexts within an academic discipline may also help EfS research to frame such enquiries in a more defined manner. Overall, these emerging fields underpin the development of an individual in terms central to the concerns of HE and, seen systemically, resonate with a deeper question of the purposes of $\mathrm{HE}$.

\section{Notes}

This paper was originally conceived of and presented at the Association for Learning Development in Higher Education (ALDinHE) Conference held at Plymouth University in 2013, where there was keen interest in developing and making explicit the links between 
sustainability and learning development (Winter and Cotton, 2013). That these two fields crossed paths at Plymouth University is no surprise, given the university's excellent track record both on sustainability, featuring regularly in the top places for the Green Gown Awards, and the People and Planet Green League, and that the university was one of the founding institutions of ALDinHE more than ten years ago. Discussions that have been taking place at and beyond the conference, and with practitioners beyond Plymouth, suggest an emerging consensus around the identity of these links and how they might best be communicated, forming the basis of this paper. We offer the ideas in this paper in the hope of continuing this discussion, but also to open up the debate beyond current interest to the wider community of practice. The Educational Development and Learning Development teams both at Plymouth University and at the University of the Arts London (UAL) work closely together and the authors would welcome feedback on any aspect of this paper and ideas for how to take this work forward.

\section{Acknowledgements}

Many thanks to Julia Dawson of the Learning Development team at Plymouth University for inspiring ideas which have helped to inform this paper (J.dawson@plymouth.ac.uk).

Many thanks also to Alex Lumley and Pat Christie of UAL for providing the context for these explorations through the Strategy for Academic Support at UAL, and for supporting the development of the learning awareness strand within the strategy.

\section{References}

ALDinHE (2013) Welcome to ALDinHE. Available at: www.aldinhe.ac.uk (Accessed: 8 August 2013).

Bateson, G. (1972) Steps to an ecology of mind. San Francisco: Chandler.

Barnett, R. (1990) The idea of higher education. London: Society for Research into Higher Education. 
Barnett. R. (2000) Realizing the university in an age of super-complexity. London: Society for Research into Higher Education and Open University Press.

Bawden, R. (2005) 'Systemic development at Hawkesbury: some personal lessons from experience', Systems Research and Behavioural Science, 22(2), pp. 151-164.

Becher, T. and Trowler, P. (2001) Academic tribes and territories: intellectual enquiry and the cultures of disciplines. $2^{\text {nd }}$ edn. London: The Society for Research into Higher Education.

Bekir S.G. and. Wiley, D.A. (2007) 'Instructional technology and objectification', Canadian Journal of Learning and Technology, 33(3) [Online]. Available at: http://www.cjlt.ca/index.php/cj|t/article/view/159/151 (Accessed: 8 June 2014).

BIS (2008-9) Low carbon and environmental goods and services: an industry analysis Update for 2008/09. Available at:

http://webarchive.nationalarchives.gov.uk/20120823131012/http://www.bis.gov.uk/a ssets/biscore/corporate/docs/l/10-795-low-carbon-goods-analysis-update-200809.pdf (Accessed: 8 June 2014).

BIS (2010) Skills for sustainable growth strategy document. Available at: https://www.gov.uk/government/uploads/system/uploads/attachment data/file/3236 8/10-1274-skills-for-sustainable-growth-strategy.pdf (Accessed: 25 January 2015).

Bone, E. and Agombar, J. (2011) First-year attitudes towards, and skills in, sustainable development. Commissioned by the HEA and NUS [Online]. Available at: http://efsandquality.glos.ac.uk/toolkit/NUS HEA 2011.pdf (Accessed: 8 June 2014).

Burgess J., Harrisson, C. and Filius, P. (1998) 'Environmental communication and the cultural politics of environmental citizenship', Environment and Planning A, 30(1), pp. 1445-1460.

Castells, M. (2001) 'Universities as dynamic systems of contradictory functions', in Muller, J., Cloete, N. and Badat, S. (eds.) Challenges of globalisation. South African debates with Manuel Castells. Cape Town: Maskew Miller Longman, pp. 206-223. 
Christie, F. and Maton, K. (2011) 'Why disciplinarity?' in Christie, F. and Maton, K. (eds.) Disciplinarity: systemic functional and sociological perspectives. London: Continuum, pp. 1-9.

Coffin, C. and Donohue, J. (2012) 'Academic literacies and systemic functional linguistics: how do they relate?', Journal of English for Academic Purposes, 11(1), pp. 64-75.

Cotton, D.R.E. and Winter, J. (2010) 'It's not just bits of paper and light bulbs': a review of sustainability pedagogies and their potential for use in higher education', in Jones, P., Selby, D. and Sterling, S. (eds.) Sustainability education: perspectives and practice across higher education. London: Earthscan, pp. 39-54.

Cotton, D., Bailey, I., Warren, M. and Bissell, S. (2009) 'Revolutions and second-best solutions: education for sustainable development in higher education', Studies in Higher Education, 34(7), pp. 719-733.

CRE-Copernicus (1994) CRE-Copernicus declaration. Geneva: Cre-Copernicus Secretariat.

Dawe, G., Jucker, R. and Martin, S. (2005) Sustainable development in higher education: current practice and future developments. A report for the Higher Education Academy. York: HEA [Online]. Available at: http://thesite.eu/sustdevinHEfinalreport.pdf (Accessed: 8 June 2014).

Deane, M. and O'Neill, P. (2011) 'Writing in the disciplines: beyond remediality', in Deane, M. and O'Neill, P. (eds.) Writing in the disciplines. Basingstoke: Palgrave Macmillan, pp. 3-11.

Drayson, R., Bone, E. and Agombar, J. (2012) Student attitudes towards, and skills in, sustainable development. Commissioned by the HEA and NUS. York: HEA. Available at: http://efsandquality.glos.ac.uk/toolkit/NUS HEA 2012.pdf (Accessed: 28 Jan 2015). 
Escotet, M.E. (2012) What is the purpose of higher education: knowledge or utility? Available at: http://miguelescotet.com/2012/what-is-the-purpose-of-highereducation-knowledge-or-utility/ (Accessed: 26 February 2013).

Forum for the Future/UCAS (2008) Future Leaders Survey 2007-8. London: Forum for the Future/UCAS [Online]. Available at:

http://www.forumforthefuture.org/sites/default/files/project/downloads/futureleaders0 708.pdf (Accessed: 26 February 2014).

Foster, J. (2011) 'Sustainability and the learning virtues', Journal of Curriculum Studies, 43(3), pp. 383-402.

Harich, J. (2010) 'Change Resistance as the crux of the environmental sustainability problem', System Dynamics Review, 26(1), pp. 35-72 [Online]. Available at: http://www.thwink.org/sustain/articles/009/ChangeResistanceAsCrux.htm (Accessed: 26 February 2014).

Hesselbarth, C. and Schaltegger, S. (2014) 'Educating change agents for sustainability learning from the first sustainability management Master of Business Administration', Journal of Cleaner Production, 62, pp. 1-13.

Hilsdon, J. (2011) 'What is learning development?', in Hartley, P., Hilsdon, J., Keenan, C., Sinfield, S. and Verity, M. (eds.) Learning development in higher education. Basingstoke: Palgrave Macmillan, pp. 13-27.

HM Government (2011) Enabling the transition to a green economy [Online]. Available at: https://www.gov.uk/government/uploads/system/uploads/attachment data/file/1834 17/Enabling the transition to a Green Economy Main D.pdf (Accessed: 8 June 2014).

Lave, J. and Wenger, E. (1991) Situated learning: legitimate peripheral participation. Cambridge: Cambridge University Press.

Lea, M. and Stierer, B. (2000) 'Editors introduction', in Lea, M. and Stierer, B. (eds.) Student writing in higher education. Buckingham: Open University Press, pp. 1-14. 
Lea, M. and Street, B. (1998) 'Student writing in higher education: an academic literacies approach', Studies in Higher Education, 23(2), pp.157-172.

Lea, M.R. and Street, B. (2006) 'The 'academic literacies' model: theory and applications', Theory Into Practice, 45(4), pp. 368-377.

Lester Pearson Institute for International Development (1992) Creating a common future: proceedings of the conference on university action for sustainable development. Halifax: Atlantic Nova Print.

Lillis, T. and Scott, M. (2007) 'Defining academic literacies research: issues of epistemology, ideology and strategy', Journal of Applied Linguistics, 4(1), pp. 5-32.

Meyer, J. and Land, R. (2003) 'Threshold concepts and troublesome knowledge: linkages to ways of thinking and practising', Enhancing teaching-learning environments in undergraduate courses, Occasional Report 4, May 2003. Edinburgh: ETL Project.

Moore, J. (2005) 'Is higher education ready for transformative learning? A question explored in the study of sustainability', Journal of Transformative Education, 3(1), pp. 76-91.

Oulton, C., Dillon, J. and Grace, M. (2004) 'Reconceptualising the teaching of controversial issues', International Journal of Science Education, 26(4), pp. 411-423.

Paris, S. (2002) Perspectives on object-centred learning in museums. Mahwah, NJ: Routledge.

Perkins, D. (2006) 'Constructivism and troublesome knowledge', in Land, R. (ed.) Overcoming barriers to student understanding: threshold concepts and troublesome knowledge. Abingdon: Routledge, pp. 33-47.

Plymouth University (PU) (2014) Seven steps to embedding sustainability in your teaching. Available at: https://www.plymouth.ac.uk/uploads/production/document/path/2/2396/7 steps to embedding sustainability.pdf (Accessed: 26 February 2014). 
Prown, J. (1982) 'Mind in matter: an introduction to material culture, theory and method', Winterthur Portfolio, 17(1), pp. 1-19. Chicago: University of Chicago Press.

Reid, A. and Petocz, P. (2006) 'University lecturers' understanding of sustainability', Higher Education, 51(1), pp. 105-123.

Ryan, A. and Cotton, D. (2013) 'Times of change: shifting pedagogy and curricula for future sustainability', in Sterling, S., Maxey, L. and Luna, H. (eds.) The sustainable university: progress and prospects. Abingdon: Routledge, pp. 151-167.

Robertson, D. (2000) 'Students as consumers: the individualization of competitive change', in Scott, P. (ed.) Higher education re-formed. London and New York: Falmer press, pp. 78-94.

Robottom, I. and Hart, P. (1993) Research in environmental education: engaging the debate. The Deakin-Griffith Environmental Education Project. Australia: Deakin University.

Sandri, O.J. (2013) 'Threshold concepts, systems and learning for sustainability', Environmental Education Research, 19(6), pp. 810-822.

Scottish Executive (2003) Life Through Learning; Learning Through Life [Online]. Available at: http://www.scotland.gov.uk/Publications/2003/02/16308/17750 (Accessed: 6 July 2014).

Skillen, J., Merten, M., Trivett, N. and Percy, A. (1998) The IDEALL approach to learning development: a model for fostering improved literacy and learning outcomes for students. Australia: University of Wollongong, Research Online. [Online]. Available at: http://ro.uow.edu.au/cgi/viewcontent.cgi?article=1149\&context=asdpapers (Accessed: 6 July 2014).

Sterling, S. (2001) Sustainable education: revisioning learning and change. Totnes: Green Books Ltd. 
Sterling, S. (2003) Whole Systems Thinking as a basis for paradigm change in education: explorations in the context of sustainability (PhD thesis). Bath: Centre for Research in Education and the Environment, University of Bath.

Sterling, S. (2004) 'Higher Education, sustainability and the role of systemic learning', in Blaze Conran, P. and Wals, A. (eds.) Higher education and the challenge of sustainability: problematics, promise and practice. London: Kluwer Academic Publishers, pp. 347-348.

Sterling, S. (2010) 'Learning for resilience or the resilient learner? Towards a necessary reconciliation in a paradigm of sustainable education', Environmental Education Research, 16(5-6), pp. 511-528.

Sterling, S. (2010-11) 'Transformative learning and sustainability: sketching the conceptual ground', Learning and Teaching in Higher Education, 5(2010-11), pp. 17-33.

Sterling, S. (2012) The future fit framework: an introductory guide to teaching and learning for sustainability in HE. York: Higher Education Academy [Online]. Available at: http://www.eauc.org.uk/the future fit framework an introductory guide 1 (Accessed: 25 January 2015).

Stibbe, A. (ed.) (2009) The handbook of sustainability literacy skills for a changing world. Totnes: Green Books Ltd.

Swales, J.M. (2009) 'When there is no perfect text: approaches to the EAP practitioner's dilemma', Journal of English for Academic Purposes, 8(1), pp. 5-13.

Tapper, J. (2004) 'Student perceptions of how critical thinking is embedded in a degree program', Higher Education Research and Development, 23(2), pp. 199-222.

Terenzini, P.T., Springer, L., Pascarella, E.T. and Nora, A. (1995) 'Influences affecting the development of students' critical thinking skills', Research in Higher Education, 36(1), pp. 23-39.

UNESCO (1990) The Talloires declaration. Gland: UNESCO. 
UNESCO (2009) Bonn declaration. Germany: UNESCO. Available at:

http://unesdoc.unesco.org/images/0018/001887/188799e.pdf (Accessed: 24 February 2015).

Velazquez, L., Munguia, N. and Sanchez, M. (2005) ‘Deterring sustainability in higher education institutions: an appraisal of the factors which influence sustainability in higher education institutions', International Journal of Sustainability in Higher Education, 6(4), pp. 383-391.

Villiers-Stuart, P. and Stibbe, A. (eds.) The handbook of sustainability literacy: skills for a changing world. Brighton: University of Brighton Faculty of Arts, Sustainability Network [Online]. Available at: http://arts.brighton.ac.uk/stibbe-handbook-ofsustainability/chapters (Accessed: 6 July 2014).

Wals, A. and Jickling, B. (2002) 'Sustainability in higher education: from doublethink and newspeak to critical thinking and meaningful learning', International Journal of Sustainability in Higher Education, 3(3), pp. 221-232.

Warburton, K. (2003) 'Deep learning and education for sustainability', International Journal of Sustainability in Higher Education, 4(1), pp. 44-56.

WCED (World Commission for Sustainable Development) (1987) Our common future, from one earth to one world. Oxford: Oxford University Press. Available at: http://www.un-documents.net/wced-ocf.htm (Accessed: 25 January 2015).

Willcocks, J. (2015, in press) 'The Power of Concrete Experience: museum collections, touch and meaning-making in art and design pedagogy', in Chatterjee, H. and Hannan, L. (eds.) Object-based learning in higher education. Surrey: Ashgate.

Wingate, U. (2006) 'Doing away with 'study skills', Teaching in Higher Education, 11(4), pp. 457-469. 
Winter, J. and Cotton, D. (2013) 'Learning development and sustainability: what are the links and how are they communicated?', Tenth Annual Conference of the Association for Learning Development in Higher Education. Plymouth University, Plymouth 26-27 March.

WWF (2005) Linking thinking: new perspectives on thinking and learning for sustainability [Online]. Available at:

http://www.eauc.org.uk/wwf linking thinking new perspectives on thinking (Accessed: 6 July 2014).

\section{Author details}

Jennie Winter is an Educational Developer in the Pedagogic Research Institute and Observatory (PedRIO), Plymouth University, UK. Jennie teaches in a range of educational areas but specialises in Education for Sustainability. Find out more about Jennie's work at https://www.plymouth.ac.uk/staff/jennie-winter.

Graham Barton, FHEA, is an Academic Support Coordinator at the University of the Arts London. Following an early career in commercial real estate as a Chartered Surveyor, Graham changed to parallel careers in performing arts (as a musician/producer) and in Higher Education (English for Academic Purposes, Learning Development). His educational interests have emerged from these personal transformations, and areas of pedagogic research interest include academic study as practice, self-enquiry for learning, and creative methodologies for developing student systemic and epistemic cognition.

Joseph Allison, team leader for Learning Development at Plymouth University, has been working with students in HE for the past seven years, supporting them in understanding the expectations of university, and encouraging them in exploring different approaches to studying and learning in order to get the most out of their studies. Areas of specific interest include student voice, criticality and its role in academia, the student experience, and education for sustainable development.

Debby Cotton is Professor of Higher Education Pedagogy and Head of Educational Development in the Pedagogic Research Institute and Observatory (PedRIO), Plymouth 
University, UK. She is a Principal Fellow of the Higher Education Academy, and sits on the editorial board of five journals. Debby has a doctorate in Environmental Education from Oxford University, and has published widely on a range of HE topics. She has recently edited a SEDA Special on Education for Sustainable Development in Educational Development, and contributed to a book on the Sustainable University (edited by Sterling, Maxey and Luna). For a full profile, please see: http://www.plymouth.ac.uk/staff/dcotton\# 